\title{
Supplementation at casing to improve yield and quality of white button mushroom
}

\author{
Yaqvob Mami ${ }^{*}$, Gholamali Peyvast ${ }^{1}$, Mahmood Ghasemnezhad ${ }^{1}$, Farhood Ziaie $^{2}$ \\ ${ }^{1}$ Department of Horticulture Science, Faculty of Agriculture, University of Guilan, Rasht, Iran; \\ *Corresponding Author: mami yad 1658@yahoo.com \\ ${ }^{2}$ Agricultural, Medical and Industrial Research School, Nuclear Science and Technology Research Institute, Karaj, Iran
}

Received 6 October 2012; revised 13 November 2012; accepted 10 December 2012

\begin{abstract}
Supplementation of substrate at casing to increase the yield and quality of mushroom [Agaricus bisporus (Lange) Sing] is an important practice in commercial production of white button mushroom. This project was done to study the effects of supplementing the compost at casing with ground corn and soybean seed applied at: $0 \mathrm{~g}$ as control, 17, 34 and $51 \mathrm{~g}$ per $17 \mathrm{~kg}$ compost on production and harvest quality of $A$. bisporus. There were significant differences between supplemented and non-supplemented substrates. The $34 \mathrm{~g}$ soybean and $51 \mathrm{~g}$ corn treatments had the highest yield. There were significant differences in quality indices of mushroom due to the type and amount of the supplement. The $51 \mathrm{~g}$ soybean supplement produced higher protein compared with other substrates. The highest vitamin C, total phenol, total soluble solids and antioxidant capacity obtained of 34 and $51 \mathrm{~g}$ soybeans or 34 and $51 \mathrm{~g}$ corn, respectively. Increased production and quality of $\boldsymbol{A}$. bisporus may be achieved by addition of suitable amounts of supplements.
\end{abstract}

Keywords: Agaricus bisporus; Compost; Corn and Soybean

\section{INTRODUCTION}

The button mushroom [Agaricus bisporus (Lange) Sing] is the most widely cultivated and consumed mushroom throughout the world and includes about $40 \%$ of total world mushroom production [1]. The production and the use of button mushrooms as fresh food have newly increased in Iran. The button mushroom will grow on composted substrates made from various materials [2]. The compost in which it grows vegetatively, and the nutritionally poor casing materials, provides suitable physical, chemical and biological conditions that stimulate initiation of fruiting body formation [3].

The casing layer, applied 14 - 16 days after spawning is an essential part of the total substrate in the artificial culture of A. bisporus. Although many different materials may function as a casing layer, peat is generally regarded as the most suitable. Because of its unique water holding and structural properties, it is widely accepted as an ideal for casing. Peat has a neutral $\mathrm{pH}$ and because of its organic content and granular structure, stays porous even after a succession of watering, holds moisture, allows appropriate gaseous exchanges and supports microbial population able to release hormone-like substances which are likely involved in stimulating the initiation of fruit bodies [4,5].

Increasing the nutritional quality of mushroom compost is a prime factor in increasing yield. The previous work showed that when compost was supplemented with various ground seed together with refined and crude seed oils and applied to the casing layer caused increases mushroom yield [6]. The increase in the number and the yield of mushrooms has also been reported when certain chemicals were sprayed as nutrient supplementation at casing [7]. Protein-rich supplements such as soybean, black beans and cowpeas added at casing significantly stimulated mushroom yield, shortened the cultivation life-cycle, and caused colonization of the substrate compared with the non-supplemented control. Biological efficiency (BE) varied from $26.1 \%$ on unsupplemented substrate to $73.1 \%$ on compost supplemented with ground soybean. There were no significant differences in mushroom yield observed among supplements evaluated [8]. Advantages of supplementing compost with protein, and/ or lipid-rich materials, such as corn (Zea mays L.) or soybean (Glycinemax L.) at spawning, casing, and later have been demonstrated [9]. Schisler, [10] reported that supplementation of mushroom compost at spawning and at casing with various refined and crude seed oils resulted in 0.45 to $0.68 \mathrm{~kg}^{-1}$ increases in mushroom yield. It was determined that the ground seed or protein-oil combinations improved sporophore yield up to $0.9-1.13$ 
$\mathrm{kg}^{-1}$. There could be a relationship between lipid metabolism and initiation of fruiting in cultivated mushroom. The reason may be behind the fact that sterols are involved in stimulating fruiting. Heating and stimulation of competitor molds present in the compost limited the rate of supplementation and benefits.

To circumvent this competition supplementation was tried at casing [11]. Vijay et al. [12] found that supplementation at spawning or casing increased the yield of the white button mushroom. However, it was more beneficial at casing. Gerrits, [13] found that supplementation at casing was better than at spawning. This is probably due to extra nutrition provided by supplements at this stage which is directly utilized by mushroom mycelia for increased yield. Supplementation at spawning is generally associated with a rise in temperature and incidence of weed moulds, which may jeopardize the yield $[14,15]$. Improved yield and BE of Pleurotus eryngii (D.C. ex Fr.) Qué, were achieved by supplementation of substrate with a commercial delayed-release nutrient and the use of casing [16].

Yield increases of $14 \%$ were achieved from cased substrates that were supplemented at time of casing with delayed-release nutrient. The use of a casing layer enhanced the yield by $141 \%$ over non-cased substrates. When casing and substrate supplementation were combined, the yield increased $179 \%$ over no cased/non-supplemented substrates [16]. For A. bisporus, yields for each successive break compost decrease mainly as a consequence of nutrient depletion in the medium [17]. Supplementation at spawning or casing with delayed-release nutrients is a practice commonly used in the commercial cultivation of $A$. bisporus. The effect of some nutrient supplementation in the casing material on crop productivity was studied by Kassim et al. [18]. The number and yield of mushrooms increased when leucine, sodium chloride and yeast extract were added to the casing at 10 $\mu \mathrm{g} /$ liter at three day intervals for seven weeks. Fruiting body size was too large to check. The best yield was obtained when the trays were treated with yeast extract. The number of days required for the appearance of primordial fruiting bodies primordia and for the harvest was reduced by $4-5$ days. The aim of this study is to evaluate the effect of ground corn and soybean seed as rich sources of protein and oil applied to casing on production and quality of white button mushroom.

\section{MATERIALS AND METHODS}

The experiments were conducted in the Agricultural Faculty of Guilan University; Rasht, Iran, in 2011-2012. The experiment was set up in a completely randomized design with 3 replications.

\subsection{Compost, Casing Soil and Supplement Preparation}

Compost bags $(60 \times 40 \times 10 \mathrm{~cm})$ containing $17 \mathrm{~kg}$ of compost derived from wheat straw and peat (as casing soil) were purchased locally (Bibi, Karaj, Iran). Compost was analyzed for chemical properties prior to use (Table 1). Corn and soybean seeds, used as supplements to the compost, were purchased locally. Seed were ground $(0.5$ $\mathrm{mm}$ screen) and autoclaved in bags (high density polyethylene bags, $30-40 \mathrm{~cm}$ ) at $110^{\circ} \mathrm{C}$ (pressure $70 \mathrm{kPa}$ ) for $15 \mathrm{~min}$. This material was mixed with peat at $0,17,34$ and $51 \mathrm{~g} / 17 \mathrm{~kg}$ compost prior to application as casing. Supplements were analyzed for nitrogen amounts prior to use (Table 2).

\subsection{Adjusting the Environmental Conditions}

The optimum conditions provided for spawn run in a room were $23^{\circ} \mathrm{C} \pm 1{ }^{\circ} \mathrm{C}$ (air), $\mathrm{RH} 90 \%$ and a $\mathrm{CO}_{2}$ level of $12,000-15,000 \mu \mathrm{g} / \mathrm{liter}$. The temperature at case run, one stage before crop initiation (up to 1 week after casing) was $24^{\circ} \mathrm{C} \pm 1{ }^{\circ} \mathrm{C}$ (air), $\mathrm{RH} 95 \%$ and $\mathrm{CO}_{2}$ level of 7500 $\mu \mathrm{g} /$ liter, and after an additional week it changed to $15^{\circ} \mathrm{C}$ $17^{\circ} \mathrm{C}$ (air), $\mathrm{RH}$ to $85 \%$ and $\mathrm{CO}_{2}$ level of $800-1000 \mu \mathrm{g} /$ liter by providing 6 air changes of $10-15$ minutes/day.

\subsection{Casing}

After completion of mycelium running, the open top of the spawn bags were covered with $4 \mathrm{~cm}$ of pasteurized casing (peat + supplement). Watering after casing was done as suggested for commercial growth $[19,20]$. The temperature and relative humidity were $24^{\circ} \mathrm{C} \pm 11^{\circ} \mathrm{C}$ and $95 \%$, respectively in this stage.

\subsection{Cropping and Harvesting}

After completion of mycelium running in the casing soil, bags were cooled to $16^{\circ} \mathrm{C}$ and maintained at this

Table 1. Compost analysis.

\begin{tabular}{cc}
\hline Organic matter & $71 \%$ \\
\hline $\mathrm{NH}_{4}$ & $0.007 \%$ \\
$\mathrm{C}$ & $40.5 \%$ \\
$\mathrm{~N}$ & $2.3 \%$ \\
Carbon/Nitrogen & $17.6 \%$ \\
$\mathrm{pH}$ & 6.8 \\
\hline
\end{tabular}

Table 2. Supplement nitrogen content.

\begin{tabular}{cc}
\hline Supplement & N\% \\
\hline Corn & 4.05 \\
Soybean & 7.76 \\
\hline
\end{tabular}


temperature and a relative humidity above $80 \%$. Sporophores were harvested before the fruiting body showed veil opening of the cap from the stipe. The yields of other parameters were recorded.

\subsection{Dry Matter Content}

Sporophores were dried at $100^{\circ} \mathrm{C}$ to determine their dry matter content.

\subsection{Total Soluble Solid (TSS)}

TSS is an index of soluble solids concentration. Homogenated ground sporophore tissue was filtered through the filter paper Whatman No. 1 by means of vacuum and the total soluble solid of the flow throughout the process was determined by a digital refractometer ATAGO PR$32 \alpha$ (ATAGO, USA Inc., Kirkland, WA). The results were expressed as Brix.

\subsection{Vitamin C Content}

Vitamin $\mathrm{C}$ was determined by the 2,6-dichlorophenolindophenol titration method, in which the dye is reduced by ascorbic acid, resulting in disappearance of the color [21].

\subsection{Protein Content}

Protein content was determined by the method of Bradford, [22] using bovine serum albumin as the standard.

\subsection{Total Phenolic Compounds}

Amounts of total phenolic compounds in fresh mushrooms were determined according to the Folin-Ciocalteu procedure [23] with some modifications. For this purpose, $0.5 \mathrm{~g}$ mushroom slices was ground in the presence of liquid nitrogen by mortar and pestle, then $10 \mathrm{~mL}$ pure methanol were added to it for extracting phenolic compounds. The extract was centrifuged with $3000 \mathrm{rpm}$ for 15 min at $4^{\circ} \mathrm{C}$ with an AVANTITM J-25 centrifuge (Beckman Instruments Inc., Fullerton, CA) and then filtered through a Whatman No. 1 filter paper. Then $300 \mu$ of methanolic extract was brought to a volume of $500 \mu \mathrm{l}$ with distilled water into test tubes, followed by $2.5 \mathrm{~mL}$ of $10 \%$ Folin-Ciocalteu reagent and allowed to stand for 6 min. Thereafter, $2 \mathrm{~mL}$ of $7.5 \%$ sodium carbonate solution were added. Each sample was allowed to stand for 90 min at room temperature in darkness and the absorbance was measured at $760 \mathrm{~nm}$ using an UV/Vis spectrophotometer model PG Instrument +80 (Leicester, UK). Results are expressed as $\mathrm{mg}$ gallic acid/100 g fresh weight. Each assay was carried out in triplicate.

\subsection{Antioxidant Capacity}

The antioxidant capacity of fresh mushroom was ana- lyzed on the base of determination of free radical-scavenging effect of antioxidants on 2,2-diphenyl-1-picrylhydrazyl (DPPH) radical according to the procedure described by Elez-Martínez and Martín-Belloso [24]. Mushroom samples were centrifuged for 15 min at $4^{\circ} \mathrm{C}$ (Beckman Instruments Inc., Fullerton, California) and filtered through Whatman No. 1 filter paper. Aliquots of $0.01 \mathrm{~mL}$ of the supernatant were mixed with $3.9 \mathrm{~mL}$ of methanolic DPPH solution and $0.09 \mathrm{~mL}$ of distilled water. The homogenate was shaken vigorously and kept in the dark for $30 \mathrm{~min}$. The absorption of the samples was measured with a CECIL CE 2021 spectrophotometer (Cecil Instruments Ltd., Cambridge, UK) at $515 \mathrm{~nm}$ for DPPH. The percentage of inhibition of the absorbance was calculated and plotted as a function of the concentration of Trolox for the standard reference data. The final DPPH value was calculated by using a calibration curve and the percentage of inhibition was determined.

\subsection{Statistical Analysis}

The data were subjected to Analysis of Variance in SAS (ver. 9, SAS, Inc., Cary, NC) and the means were separated using Tukey's test.

\section{RESULTS}

Our results indicated that different levels of supplements affected the yield and the harvest quality. Yield, vitamin C, TSS, protein, antioxidant capacity and total phenol were the lowest, when the compost was not treated with the additives. Soybean at $34 \mathrm{~g}$ produced better yield, fruit number (small, average and total) and dry matter compared with other treatments. Soybean (34 g) and corn (51 g) were not different (Figures 1-5). The highest amounts of TSS and total phenol were produced by adding the corn $(51 \mathrm{~g})$. TSS and total phenol content did not differ significantly with CR $34 \mathrm{~g}$ and CR $51 \mathrm{~g}$ (Figures 6 and 10). Most Vitamin $\mathrm{C}$ content; was obtained from the soybean (34 and $51 \mathrm{~g})$. The highest protein and antioxidant capacities (AC) in mushrooms were due to the use of soybean $(51 \mathrm{~g})$ and corn $(34 \mathrm{~g})$, respectively. AC did not differ significantly with CR $34 \mathrm{~g}$ and CR 51 g (Figures 7-9).

\section{DISCUSSION}

Application of a casing layer for $A$. bisporus production is essential. Casing layer depth, chemical and microbial composition, physical properties and moisture content of the casing layer play important roles in yield and quality of mushrooms [25-30]. Limited information is available regarding the usage of supplements at casing versus at spawning for improvement of production and mushroom quality. Supplementing substrate at casing is a 


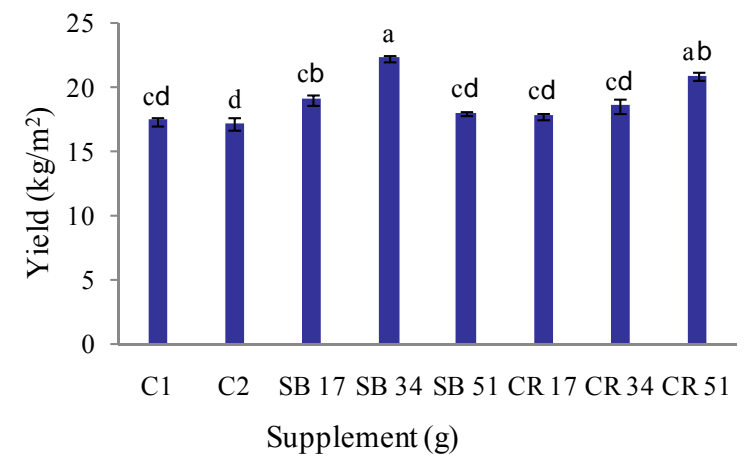

Figure 1. Effect of supplements in case soil on yield in $A$. bisporus. C1 (Control for soybean), C2 (Control for corn), $\mathrm{SB}$ (Soybean) and CR (Corn) $(\mathrm{n}=3)$.

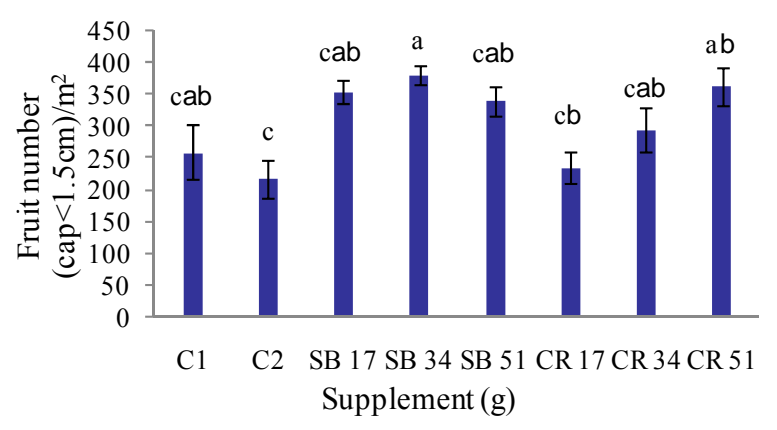

Figure 2. Effect of supplements in case soil on fruit number (small) in A. bisporus. C1 (Control for soybean), C2 (Control for corn), SB (Soybean) and CR (Corn) $(n=3)$.

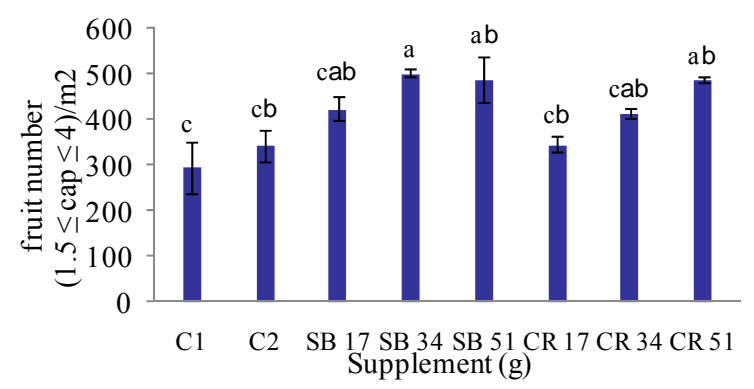

Figure 3. Effect of supplements in case soil on fruit number (averege) in A. bisporus. C1 (Control for soybean), C2 (Control for corn), SB (Soybean) and CR (Corn) $(\mathrm{n}=3)$.

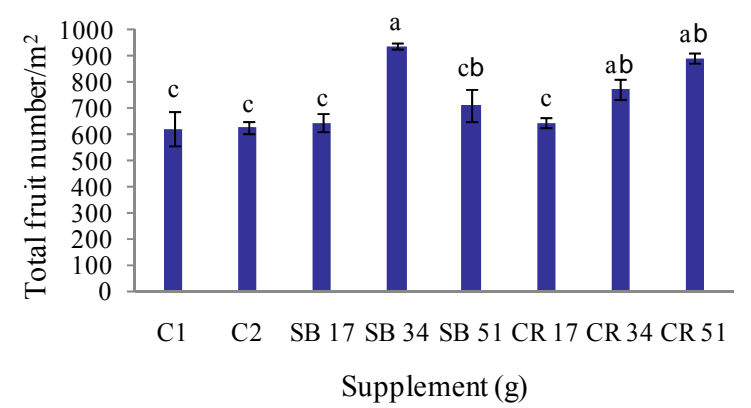

Figure 4. Effect of supplements in case soil on total fruit number in $A$. bisporus. C1 (Control for soybean), C2 (Control for corn), SB (Soybean) and CR (Corn) $(\mathrm{n}=3)$.

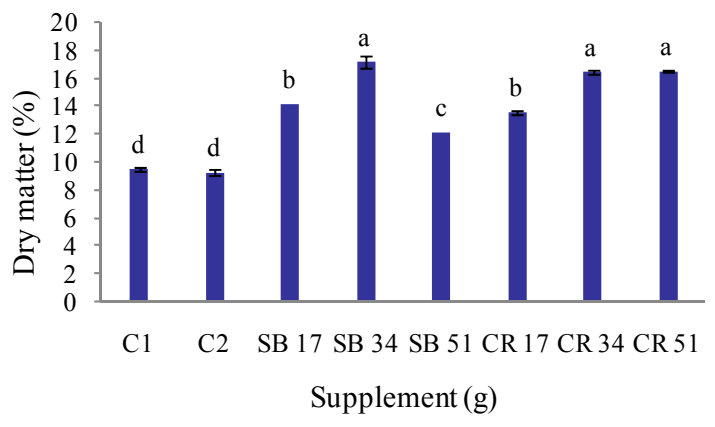

Figure 5. Effect of supplements in case soil on dry matter in A. bisporus. C1 (Control for soybean), C2 (Control for corn), SB (Soybean) and CR (Corn) $(\mathrm{n}=3)$.

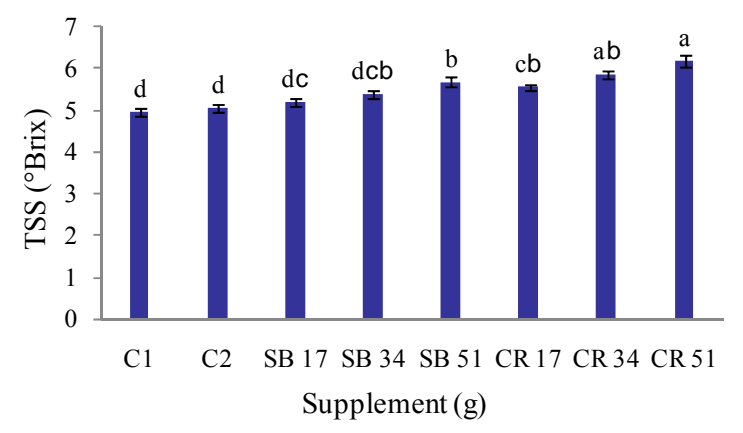

Figure 6. Effect of supplements in case soil on total solid soluble in A. bisporus. C1 (Control for soybean), C2 (Control for corn), SB (Soybean) and CR (Corn) $(\mathrm{n}=3)$.

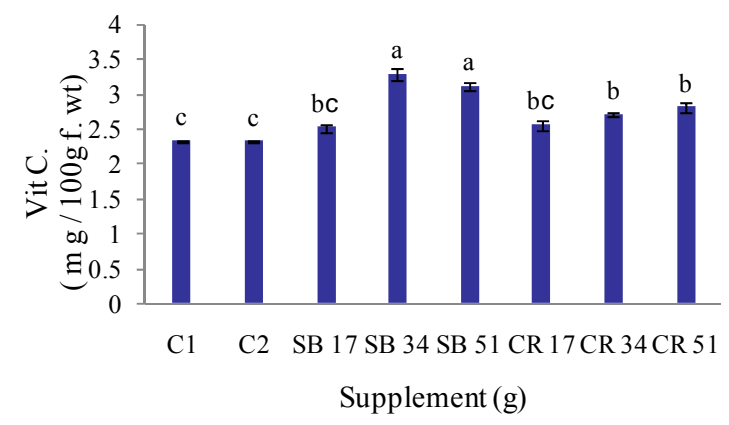

Figure 7. Effect of supplements in case soil on vit C. in $A$. bisporus. C1 (Control for soybean), C2 (Control for corn), $\mathrm{SB}$ (Soybean) and CR (Corn) $(\mathrm{n}=3)$.

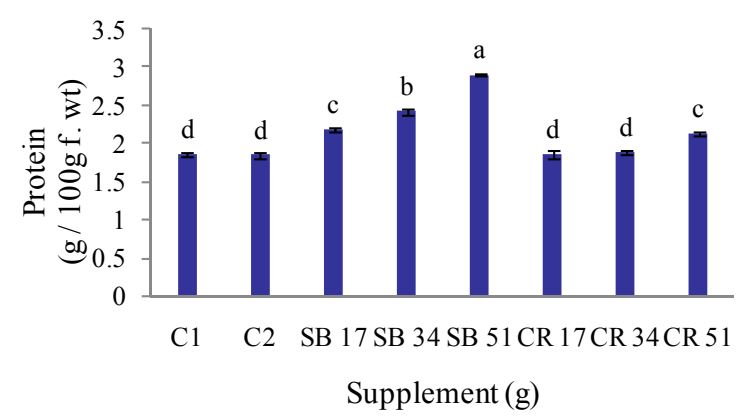

Figure 8. Effect of supplements in case soil on protein in A. bisporus. C1 (Control for soybean), C2 (Control for corn), SB (Soybean) and CR (Corn) $(\mathrm{n}=3)$. 


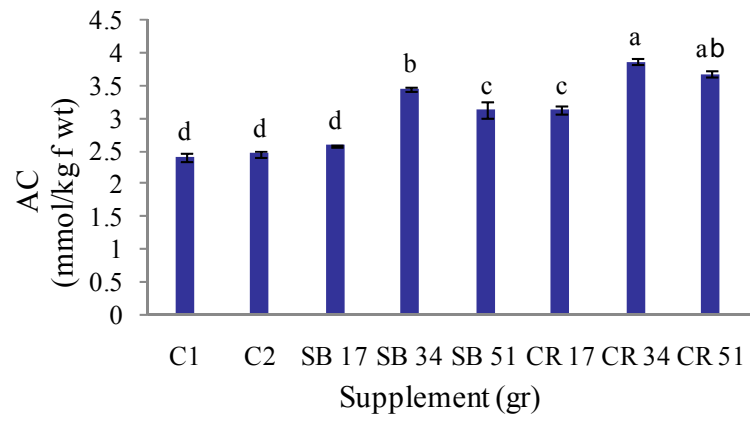

Figure 9. Effect of supplements in case soil on antioxidant capacity in A. bisporus. C1 (Control for soybean), $\mathrm{C} 2$ (Control for corn), SB (Soybean) and CR (Corn) $(\mathrm{n}=$ $3)$.

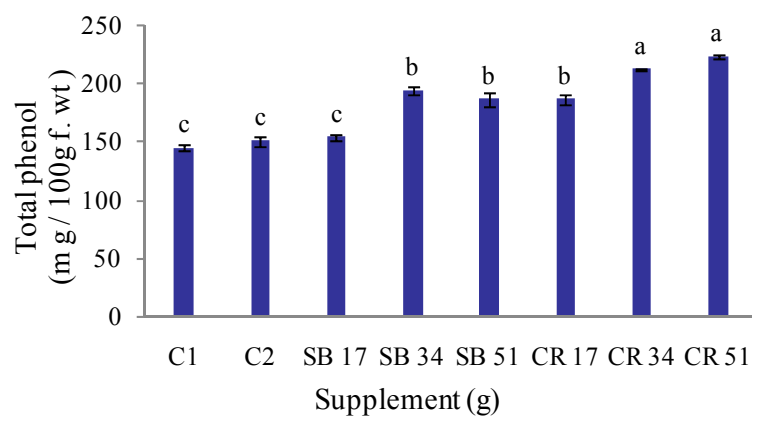

Figure 10. Effect of supplements in case soil on total phenol in A. bisporus. C1 (Control for soybean), C2 (Control for corn), SB (Soybean) and CR (Corn) $(\mathrm{n}=3)$.

relatively easy and low-cost cultural practice that may successfully be used to enhance the yield, BE and maximize the utilization of substrate. Since microbial populations in casing material are important in promoting fructification in A. bisporus, supplementing at casing can also affect microorganism populations. A direct correlation between the mushroom antioxidant capacity and total phenolic content had been reported in the light of the antioxidant action raised by other substances such as tocopherols and $\beta$-carotene [31-33]. However, increased antioxidant capacity after the supplementation with soybean could be also related to high content of polyphenolic isoflavonoids such as genistein, genistin, daidzein, daidzin, formononetin, and afrormosin in soybean [34]. Vijay et al. [12] indicated that supplementation at spawning, or at casing, significantly increased the yield. However, it was more beneficial at casing. Gerrits [13] found that supplementation at casing was better than at spawning. This is probably due to the fact that extra nutrition was provided by the supplements at this stage which is directly utilized by mycelia. Contrary to the casing process supplementation at spawning is generally associated with a rise in temperature and incidence of weed moulds, which may jeopardize the yield. Similar results have been reported $[13,14,35]$. In lipid metabolism, studies concerned with A. bisporuss howed that the mushroom yield was increased by the use of seed oils [7,36]. Carbon supplied to the compost in oil supplementation at casing was utilized to synthesize mannitol and fatty acids [37]. Mannitol is the single largest component of the dry matter in the mushroom comprising as much as $19 \%$ of dry weight. Mannitol provides turgor pressure for support of the fruit body and for the considerable extension growth which occurs [38]. Due to our results, supplementation with ground corn and soybean seeds increased the yield and quality of $A$. bisporus more than control treatment. Consequently, we can recommend the supplementation with corn and soybean seeds at casing as a good practice to increase the production and mushroom quality.

\section{CONCLUSION}

We found that yield and quality of mushroom can be improved by using the supplements at casing soil. This experiment also, showed that treatments of soy bean 34 and corn 51 induced better yields compared with other treatments. In addition, amounts of quality indices in mushrooms were different among supplemented composts with soybean and corn.

\section{ACKNOWLEDGEMENTS}

Authors acknowledge the support of University of Guilan, Rasht, Iran.

\section{REFERENCES}

[1] Giri, S.K. and Prasad S. (2007) Drying kinetics and rehydration characteristics of microwave vacuum and convective hot-air dried mushrooms. Journal of Food Engineering, 78, 512-521. doi:10.1016/j.jfoodeng.2005.10.021

[2] Delphina, P.M. and Royse, D.J. (2008) The influence of spawn type and strain on yield, size and mushroom solids content of Agaricus bisporus produced on non-composted and spent mushroom compost. Bioresource Technology, 99, 3205-3212. doi:10.1016/j.biortech.2007.05.073

[3] Gerrits, J.P.G. (1974) Development of a synthetic compost for mushroom growing based on wheat straw and chicken manure. Netherlands Journal of Agricultural Science, 22, 175-194.

[4] Eger, G. (1972) Experiments and comments on the action of bacteria on sphorophore initation in Agaricusbisporus. Mushroom Science, 8, 719-725.

[5] Hayes, W.A. (1981) Interrelated studies of physical, chemical and biological factors in casing soils and relationships with productivity in commercial culture of Agaricusbisporus. Mushroom Science, 11, 103-129.

[6] Schisler, L.C. and Sinden, J.W. (1966) Nutrient supplementation of mushroom compost at casing. Canadian Journal of Botany, 4, 287-293.

[7] Sing, R.N. and Jain, V.B. (1982) Nutrient supplementa- 
tion for good yield of button mushroom. Indian Phytopathology, 35, 535-536.

[8] Coello-Castillo, M.M., Sánchez, J.E. and Royse, D.J. (2009) Production of Agaricus bisporus on substrates pre colonized by Scytalidium thermophilum and supplemented at casing with protein-rich supplements. Bioresource Technology, 100, 4488-4492.

doi:10.1016/j.biortech.2008.10.061

[9] Carroll, A.D. and Schisler, L.C. (1976) Delayed release nutrient supplement for mushroom culture. American Society for Microbiology, 31, 499-503.

[10] Schisler, L.C. (1967) Stimulation of yield in the cultivated mushroom by vegetable oils. American Society for Microbiology, 15, 844-850.

[11] Sinden, J.W. and Sehialer, L.C. (1962) Nutrient supplementation of mushroom compost at casing. Mushroom Science, 5, 267-280.

[12] Vijay, B., Sharma, S.R. and Lakhanpal, T.N. (2002) Effect of treating post-composting with different concentrations of formaldehyde on the yield of Agaricus bisporus. Mushroom Biology and Mushroom Products, 239-242.

[13] Gerrits, J.P.G. (1986) Supplementation with formaldehyde treated soybean meal. Journal of Mushroom, 161, 169174.

[14] Dhar, B.L. and Kapoor, J.N. (1990) Inhibition of growth of Agaricusbisporus by systemic fungicides. Indian Phytopathology, 43, 473-474.

[15] Vijay, B. and Gupta, Y. (1992) Studies on fungal competitors of Agaricusbisporus. Journal Indian Phytopathology, 45, 228-238.

[16] Rodriguez Estrada, A.E., Jimenez-Gasco, M.D.M. and Royse, D.J. (2009). Improvement of yield of Pleurotuseryngii var. eryngii by substrate supplementation and use of a casing overlay. Bioresource Technology, 100, 52705276. doi:10.1016/j.biortech.2009.02.073

[17] Royse, D.J., Sanchez, J.E., Beelman, R.B. and Davidson, J. (2008) Re-supplementing and recasing mushroom (Agaricus bisporus) compost for a second crop. World Journal of Microbiology and Biotechnology, 24, 319-325. doi:10.1007/s11274-007-9473-9

[18] Kassim, M.Y., Khalie, L.A.S. and Al Rahmah, A.N. (1990) Effects of casing soil amendments and nutrient supplementation on mushroom cropping. Agricultural Science, 2, 225-230.

[19] Randle, P.E. (1984) Supplementation of mushroom compost: A review. Mushroom Journal, 151, 241-269.

[20] Shandilya, T.R. (1986) Effect of different pasteurized compost on the yield of Agaricus bisporus. Indian Journal of Plant Pathology, 4, 89-90.

[21] Association of Official Analytical Chemists (AOAC) (2002) Official methods of analysis of the association of official analytical chemists. 16th Edition, AOAC, Washington DC.

[22] Bradford, M.M. (1976) A rapid and sensitive method for the quantitation of microgram quantities of protein utilizing the principle of protein-dye binding. Analytical Biochemistry, 72, 248-254.

\section{doi:10.1016/0003-2697(76)90527-3}

[23] Singleton, V.L., Orthofer, R. and Lamuela-Raventos, R.M. (1990) Analysis of total phenols and other oxidation substrates and antioxidants by means of Folin-Ciocalteu reagent. Oxidants and Antioxidants, 299, 152-178. doi:10.1016/S0076-6879(99)99017-1

[24] Elez-Martínez, P. and Martín-Belloso, O. (2007) Effects of high intensity pulsed electric field processing conditions on vitamin $\mathrm{C}$ and antioxidant capacity of orange juice and gazpacho, a cold vegetable soup. Food Chemistry, 102, 201-209. doi:10.1016/i.foodchem.2006.04.048

[25] Cochet, N., Gillman, A. and Lebeault, J.M. (1992) Some biological characteristics of the casing soil and their effect during Agaricus bisporus fructification. Acta Biotechnologica, 12, 411-419. doi:10.1002/abio.370120510

[26] Gulser, C. and Peksen, A. (2003) Using tea waste as a new casing material in mushroom (Agaricus bisporus (L.) Sing.) cultivation. Bioresource Technology, 88, 153-156. doi:10.1016/S0960-8524(02)00279-1

[27] Kalberer, P.P. (1985) Influence of the depth of the casing layer on the water extraction from casing soil and substrate by the sporophores, on the yield and on the dry matter content of the fruit bodies of the first three flushes of the cultivated mushroom Agaricus bisporus. Scientia Horticulturae, 27, 33-43. doi:10.1016/0304-4238(85)90052-4

[28] Pardo, A., DeJuan, J.A. and Pard, J.E. (2002) Bacterial activity in different types of casing during mushroom cultivation (Agaricus bisporus (Lange) Imbach). Acta Alimentaria, 31, 327-342. doi:10.1556/AAlim.31.2002.4.3

[29] Peyvast, Gh., Shahbodaghi, J., Ramezani-Kharazi, P. and Olfati, J.A. (2007) Performance of tea waste as a peat alternative for bottom mushroom (Agaricus bisporus (Lange) Sing) cultivation. Biosciences, Biotechnology Research Asia, 4, 489-494.

[30] Schroeder, G.M. and Schisler, L.C. (1981) Influence of compost and casing moisture on size, yield and dry weight of mushrooms. Mushroom Science, 11, 495-509.

[31] Barros, L., Falcao, S., Baptista, P., Freire, C., Vilas-Boas, M. and Ferreira, I.C.F.R. (2008) Antioxidant activity of Agaricus sp. mushrooms by chemical, biochemical and electrochemical assays. Food Chemistry, 111, 61-66. doi:10.1016/j.foodchem.2008.03.033

[32] Cheung, L.M., Cheung, P.C.K. and Ooi, V.E.C. (2003) Antioxidant activity and total phenolics of edible mushroom extracts. Food Chemistry, 81, 249-255. doi:10.1016/S0308-8146(02)00419-3

[33] Kim, M.Y., Seguin, J.K., Ahn, J.J., Kim, S.C., Chun, E.H., Kim, S.H., Seo, E.Y., Kang, S.L., Kim, Y.J., Park, R. and Chung, I.M. (2008) Phenolic compound concentration and antioxidant activities of edible and medicinal mushrooms from Korea. Journal of Agricultural and Food Chemistry, 56, 7265-7270. doi:10.1021/jf8008553

[34] Lachman, J., Pivec, V., Rehakova, V. and Hubacek, J. (1990) Polyphenols and isoflavonoids of soybean (Glycine max (L.) Merr). Rostlinna Vyroba, 36, 295-301.

[35] Mamiro, D.P. and Royse, D.J. (2008) The influence of spawn type and strain on yield, size and mushroom solids 
content of Agaricus bisporus produced on non-composted and spent mushroom compost. Bioresource Technology, 99, 3205-3212. doi:10.1016/j.biortech.2007.05.073

[36] Mau, J.L., Beelman, R.B., Ziegler, G.R. and Royse, D.J. (1991) Effect of nutrient supplementation on flavour, quality and shelf life of the cultivated mushroom, Agaricus bisporus. Mycologia, 83, 142-149.

doi: $10.2307 / 3759929$
[37] Holtz, R.B. and schisler, L.C. (1986) Utilization of fatty acids by Agaricus bisporus in commercial culture. $\mathrm{My}$ cologia, 78, 722-727. doi:10.2307/3807516

[38] Holtz, R.B. (1971) Qualitative and quantitative analyses of free neutral carbohydrates in mushroom tissue by gasliquid chromatography and mass spectrometry. Journal of Agricultural and Food Chemistry, 19, 1272-1273. doi:10.1021/jf60178a052 